\title{
Keratoplasty á Chaud, Limbal Autotransplantation and Transplantation of Amniotic Membrane in the Management of Severe Chemical Burns of the Eye
}

\author{
A. TRBOLOVÁ ${ }^{1}$, I. KOZÁK $^{2}$, L. KOLODZIEYSKI ${ }^{3}$, T. JUHÁS ${ }^{2}$, V. LEDECKÝ ${ }^{1}$
}

${ }^{1}$ Department of Surgery and Ophthalmology, University of Veterinary Medicine, Košice, Slovak Republic ${ }^{2}$ Department of Ophthalmology, Šafárik Medical School, Košice, Slovak Republic

${ }^{3}$ Department of Pathology, University of Veterinary Medicine, Košice, Slovak Republic

Received February 18, 2003

Accepted September 22, 2003

Abstract

Trbolová, A., I. Kozák, L. Kolodzieyski, T. Juhás, V. Ledecký: Keratoplasty á Chaud, Limbal Autotransplantation and Transplantation of Amniotic Membrane in the Management of Severe Chemical Burns of the Eye. Acta Vet. Brno 2003, 72: 571-576.

The purpose of this study was to assess the efficacy and safety of the management of severe chemical eye injuries using early keratoplasty combined with limbal autotransplantation and amniotic membrane transplantation. Ten New Zealand white male rabbits were used in the experiment. All procedures followed the rules of ARVO Statement for the Use of animals in Ophthalmic Research. Under general anaesthesia, injury was induced using a solution of 1.5 $\mathrm{N} \mathrm{NaOH}$. Surgery was done within 3 days of injury. Clinical examination was performed at 2 weeks, 4 weeks, 3 months, and 6 months post-operatively. This included evaluation for corneal oedema, opacification, vascularization, erosion, limbal ischaemia, tear film stability and postoperative uveitis. Histopathologic studies were also performed. Early post-operative oedema and uveitis cleared at 4 weeks after treatment. The grafts were transparent during the two months period of cyclosporin treatment after which opacification and vascularization occurred. Tear film was stable at the end of follow-up and no erosions were noted. Histologic sections of the corneal grafts showed rejection reaction and some areas of limbal autografts showed slight tissue oedema with lymphocytes and lymphoblast-like cells. Early keratoplasty with limbal autotransplantation and amniotic membrane transplantation promotes healing of damaged ocular surface after severe alkali burn. Clarity of corneal allografts is maintained during immunosuppressive therapy after which it is lost and graft reaction occurs. A controlled study to compare early versus late keratoplasty combined with limbal autotransplantation is needed to assess the proper timing of treatment.

Chemical eye injury, limbal autotransplantation, early keratoplasty, amniotic membrane, ocular surface healing

Chemical injuries of the eye may produce extensive damage to the ocular surface. Such injuries result in immediate damage to corneal and conjunctival epithelium, corneal stroma and limbus. The latter is a carrier of corneal stem cells and is indispensable for the maintenance of a healthy corneal epithelial surface. These limbal stem cells act as a proliferative source for the regeneration of the corneal epithelial cells (Schermer et al. 1986). Severe chemical burns may cause persistent epithelial defects, vascularization, scarring and keratinization (Keny on and Tseng 1989). Thus, one important strategy of managing ocular burns in the acute stage is to promote epithelization, reduce inflammation, and prevent progressive tissue melting (W agoner 1997).

Limbal stem cells transplantation, preferably from the contralateral eye, is a currently available technique to re-estabilish a normal phenotype of corneal epithelium after severe chemical injuries. Amniotic membrane transplantation in the acute stage is an additional procedure used to promote epithelial healing and to reduce inflammation, vascularization and scarring after alkali burns (Meller et al. 2000). Even these two procedures done simultaneously may not prevent late corneal opacification. Such injuries may require

Address for correspondence:

MVDr. Alexanda Tibolova, PhD

MVDr. Alexandra Trbolova, PhD

Department of Surgery and Ophthalmology

Komenského 73, 04011 Košice, Slovak Republic
Phone: +421556339040

Fax: +421 556337832

http://www.vfu.cz/acta-vet/actavet.htm 
penetrating keratoplasty a few months after the original injury to restore corneal transparency in tectonically stable eyes.

Immediate keratoplasty, combined with limbal autograft transplantation (LAT) and amniotic membrane transplantation, was investigated as a treatment for alkali chemical eye surface injury in rabbits. Using clinical and histopathological parameters, we evaluated the course of healing and the final clinical status of the treated eyes.

Early treatment of severe chemical injuries is of paramount importance for the ultimate prognosis. Acute changes caused by chemicals usually have chronic sequelae in spite of currently available aggressive treatment. In this study we observed the therapeutic effectiveness of immediate keratoplasty combined with limbal autotransplantation (LAT) and transplantation of amniotic membrane (AM) in severe experimental alkali injury.

\section{Materials and Methods}

Ten white New Zealand male rabbits weighing 2.5-3.5 kg were used. All rabbits were handled in compliance with the Association for Research and Vision in Ophthalmology (ARVO) Statement for the Use of Animals in Ophthalmic Research. Prior to acceptance for use, all rabbits underwent a baseline ocular examination to rule out pre-existing anterior segment anbormalities. The chemical injuries and all surgical procedures were preceded by general anaesthesia. Premedication was intramuscular atropin $0.05 \mathrm{mg} / \mathrm{kg}$ (Atropin Spofa inj. $0.5 \mathrm{mg} / \mathrm{ml}$ ). General anaesthesia was induced with xylazin hydrochloride (Rometar $2 \%$, a.u.v.) $5 \mathrm{mg} / \mathrm{kg}$ and ketamin hydrochloride (Narkamon $5 \%$, a.u.v.) $40 \mathrm{mg} / \mathrm{kg}$.

One eye of each rabbit received a drop of tetracaine for local anaesthesia after which $1.5 \mathrm{~N} \mathrm{NaOH}$ solution was spread over the ocular surface with a cotton tipped applicator and left for 10 seconds. The injured area was then continually washed for 5 minutes by saline solution. Surgery in each rabbit was performed within 3 days after the chemical injury.

Amniotic membrane with attached placenta was acquired during Caesarean delivery from clinically healthy cow. Under sterile conditions amniotic membrane/placenta complex was repeatedly washed in saline solution. Subsequent blunt preparation separated the amniotic membrane from chorion and other decidual tissue and amniotic membrane was cut to pieces $5 \times 5 \mathrm{~cm}$. The tissue was kept in solution containing $50 \mu \mathrm{g} / \mathrm{ml}$ penicillin, 50 $\mu \mathrm{g} / \mathrm{ml}$ streptomycin and $100 \mu \mathrm{g} / \mathrm{ml}$ naomycin. The pieces of amniotic membrane were thus preserved in refrigerator at $2{ }^{\circ} \mathrm{C}$ and used the following day for surgery.

Corneal grafts were collected from euthanised rabbits of the same breed and sex, aged 1-1.5 years and weighing $3-4 \mathrm{~kg}$. The rabbits had been used previously in an orthopedic experiment. These donor corneas were kept in Optisol solution for 10 days at $4{ }^{\circ} \mathrm{C}$.

Limbal grafts of 2.5 - $3 \mathrm{~mm}$ width and from 11-2 o'clock position were acquired from each contralateral uninjured eye. The donor groove was covered by adjacent conjunctiva using non-resorbable suture (Ethilon 10.0 with microfilament polyamide fiber and atraumatic $6 \mathrm{~mm}$ "micro-point" needle with $3 / 8$ curvature).

The donor corneal button was prepared using $8.5 \mathrm{~mm}$ punch and placed in a Petri dish with saline solution. The central corneal portion of the injured eye was trephined using $8.0 \mathrm{~mm}$ Barron trephine; the presence of aqueous humour indicated penetration into the anterior chamber. The rest of the button was released by circumferentially cutting the edges by curved scissors. The recipient eye was washed with saline solution and a surgical iris coloboma was produced at $12.00 \mathrm{~h}$. Bleeding from the iris was stopped by microcautery and blood was washed out of the surgical field. Viscoelastic material was applied to recipient's eye anterior chamber and the donor cornea was placed in the recipient stromal bed. Four cardinal Ethilon 10.0 sutures fixed the donor button and eight additional interrupted sutures were applied to attach the button. Balanced saline solution was used to wash the anterior chamber and test the competency of the suturing.

Next amniotic membrane was applied on top of the corneal transplant and the ocular surface using interrupted 8.0 Vicryl sutures. Its peripheral border was $5 \mathrm{~mm}$ from the limbus.

In the post-operative period the treated eyes received Infectoflam ${ }^{\circledR}$ (gentamycin + fluorometholone, NOVARTIS) eyedrops 5 times a day for 1 month and $2 \%$ cyclosporine eyedrops two times a day for 2 months. Each rabbit was examined clinically at 2 weeks, 4 weeks, 3 months, and finally at 6 months after surgery. The extent of oedema, vascularization, blepharospasm, conjunctival hyperemia, limbal ischaemia and signs of uveitis was measured using biomicroscopy. Fluorescein was used to test for erosion and tear film stability. Each parameter was scored as follows: 0-absent, 1-mild, 2-moderate, 3-severe (see tables). Graft assessment was performed by slit lamp examination. Diagnosis of allograft rejection was based on oedema, lack of clarity, inflammation and, neovascularization of the graft. At the end of follow-up period the rabbits were euthanised and the treated eyes were taken for histopathologic examination. Microscopic sections stained with haematoxylin and eosin were studied under different magnification. The specimens were photographed using the Photo Microscop Nikon, Japan with digital camera COOLPIX 950. 


\section{Results}

\section{Clinical examination}

Preoperative ocular surface damage was successfully induced in all 10 rabbits (Plate XIII, Fig.1). The surgery was done within three days after alkali injury. All animals tolerated the combined surgical procedure well.

The donor buttons and the recipient corneas were evaluated separately for oedema, opacification and vascularization. Eight of the 10 eyes had slight oedema of both donor and recipient portions of the cornea at 2 weeks. This showed improvement at 4 weeks post surgery but deteriorated after topical cyclosporin was stopped at 2 months (Plate XIII, Fig. 2). Opacification of the grafts and neovascularization followed the same clinical pattern. Vascularization was most intense in the area of limbal autografts (Table 1,2,3).

Table 1

Corneal oedema: donor button/recipient cornea

\begin{tabular}{|l|l|l|l|l|}
\hline Grade & $2^{\text {nd }}$ week & $4^{\text {th }}$ week & $3^{\text {rd }}$ month & $6^{\text {th }}$ month \\
\hline 0 & $7 / 3$ & $8 / 4$ & $5 / 2$ & $3 / 1$ \\
\hline 1 & $3 / 5$ & $2 / 6$ & $3 / 5$ & $4 / 6$ \\
\hline 2 & $0 / 2$ & $0 / 0$ & $2 / 3$ & $1 / 1$ \\
\hline 3 & $0 / 0$ & $0 / 0$ & $0 / 0$ & $0 / 0$ \\
\hline
\end{tabular}

Grade: 0 - no oedema, 1 - mild epithelial, 2 - moderate stromal, 3 - severe oedema icluding all corneal layers

Table 2

Corneal opacification: donor button/recipient cornea

\begin{tabular}{|l|l|l|l|l|}
\hline Grade & $2^{\text {nd }}$ week & $4^{\text {th }}$ week & $3^{\text {rd }}$ month & $6^{\text {th }}$ month \\
\hline 0 & $10 / 3$ & $9 / 3$ & $8 / 2$ & $1 / 0$ \\
\hline 1 & $0 / 5$ & $1 / 5$ & $1 / 4$ & $1 / 0$ \\
\hline 2 & $0 / 2$ & $0 / 2$ & $1 / 4$ & $4 / 5$ \\
\hline 3 & $0 / 0$ & $0 / 0$ & $0 / 0$ & $2 / 3$ \\
\hline
\end{tabular}

Grade: 0- clear cornea, 1- mild localized reduction of corneal transparency, 2- diffuse reduction in corneal transparency, 3-total corneal opacification

Table 3

Vascularization: donor button/recipient cornea

\begin{tabular}{|l|l|l|l|l|}
\hline Grade & $2^{\text {nd }}$ week & $4^{\text {th }}$ week & $3^{\text {rd }}$ month & $6^{\text {th }}$ month \\
\hline \hline 0 & $10 / 10$ & $10 / 8$ & $7 / 5$ & $2 / 0$ \\
\hline 1 & $0 / 0$ & $0 / 2$ & $2 / 2$ & $1 / 1$ \\
\hline 2 & $0 / 0$ & $0 / 0$ & $1 / 2$ & $1 / 1$ \\
\hline 3 & $0 / 0$ & $0 / 0$ & $0 / 1$ & $2 / 4$ \\
4 & $0 / 0$ & $0 / 0$ & $0 / 0$ & $2 / 2$ \\
\hline
\end{tabular}

Grade: 0 - no vascularization, 1- vascularization in one quadrant of the cornea, 2- vascularization in two quadrants, 3- vascularization in three quadrants, 4- total corneal vascularization

Epithelial continuity in the transplant eyes was also evaluated. Erosion was noted in 4 eyes at 3 months. At 6 months two eyes exhibited deep corneal ulcer which spontaneously perforated and therefore the number of eyes at the final exam was eight. The remaining eyes showed no erosion at 6 months (Table 4). Tear film stability was defective in 8 eyes out of 10 at first follow-up and improved to 3 out of 8 eyes at 6 months (Table 6). Limbal 
Table 4

Erosion

\begin{tabular}{|l|l|l|l|l|}
\hline Grade & $2^{\text {nd }}$ week & $4^{\text {th }}$ week & $3^{\text {rd }}$ month & $6^{\text {th }}$ month \\
\hline 0 & 9 & 6 & 6 & 8 \\
\hline 1 & 1 & 3 & 3 & 0 \\
\hline 2 & 0 & 1 & 1 & 0 \\
\hline 3 & 0 & 0 & 0 & 0 \\
\hline
\end{tabular}

Grade: 0 - no erosion, 1 - defect of $25 \%$ of epithelial area, 2 - defect of $50 \%$ of epithelial area, $3-$ defect of $75 \%$ of epithelial area

Table 5

Limbal ischeamia

\begin{tabular}{|l|l|l|l|l|}
\hline Grad & $2^{\text {nd }}$ week & $4^{\text {th }}$ week & $3^{\text {rd }}$ month & $6^{\text {th }}$ month \\
\hline 0 & 0 & 1 & 2 & 4 \\
\hline 1 & 10 & 8 & 6 & 4 \\
\hline 2 & 0 & 1 & 2 & 0 \\
\hline 3 & 0 & 0 & 0 & 0 \\
\hline
\end{tabular}

Grade: 0 - no ischaemia, 1 -ischaemia of $1 / 3$ of limbal circumference, 2 -ischaemia of $1 / 2$ of limbal circumference, 3 - total limbal ischaemia

Table 6

Tear film stability

\begin{tabular}{|l|l|l|l|l|}
\hline Grade & $2^{\text {nd }}$ week & $4^{\text {th }}$ week & $3^{\text {rd }}$ month & $6^{\text {th }}$ month \\
\hline 0 & 0 & 2 & 4 & 5 \\
\hline 1 & 6 & 6 & 3 & 2 \\
\hline 2 & 3 & 2 & 3 & 0 \\
\hline 3 & 1 & 0 & 0 & 1 \\
\hline
\end{tabular}

Grade: 0 - normal tear film, 1 - tear film defect in area of 25\%,2 - tear film defect in area of 50\% 3 - tear film defect

Table 7

Postoperative uveitis

\begin{tabular}{|l|l|l|l|l|}
\hline Grade & $2^{\text {nd }}$ week & $4^{\text {th }}$ week & $3^{\text {rd }}$ month & $6^{\text {th }}$ month \\
\hline 0 & 5 & 7 & 10 & 8 \\
\hline 1 & 2 & 1 & 0 & 0 \\
\hline 2 & 1 & 2 & 0 & 0 \\
\hline 3 & 2 & 0 & 0 & 0 \\
\hline
\end{tabular}

Grade: 0 - no signs of intraocular inflammation, 1- mild uveitis, 2- moderate uveitis, 3 - severe uveitis with hypopyon in anterior chamber and anterior synechiae

ischaemia, most marked early post-operatively, improved at the 6 months exam (Table 5). Postoperative uveitis of various degrees was present at earlier examinations, but had entirely disappeared by the $3^{\text {rd }}$ post-operative month (Table 7).

Histopathological examination

Histopathological findings consistent with immune rejection of the corneal graft were present in each specimen. Corneal stroma was thicker. Stromal cellular infiltration with lymphocytes was present and scattered blood vessels in the cornea were observed. Epithelial 
changes were noticed at the graft/recipient border. Sections of limbal autograft area showed slight tissue oedema with lymphocytes and lymphoblast-like cells interspersed among blood vessels.

\section{Discussion}

Keratoplasty was performed in a standard manner using interrupted sutures. Because keratoplasty for alkali burns is a high-risk procedure (Kramer 1983), sustained levels of immunosuppressive drug must be achieved to protect the corneal graft from immune reaction. Topical 2\% cyclosporin (CsA) drops were used for 2 months to prolong graft survival. During this period the grafts were clear compared to the peripheral recipient cornea (Fig. 2). However, after discontinuation of CsA treatment, irreversible rejection in all corneal grafts was noted within 3-4 weeks. Similar findings have been observed by others (Mahlberg et al. 1997).

As noted, despite keratoplasty, the overall prognosis for visual recovery after alkali injuries is guarded. In a published study, Kramer (1983) suggested a numerical grading system for assessing severity of the effects of alkali burn with regard to intended keratoplasty. He used corneal vascularization, opacification, sensation and tear production as cardinal signs of prognosis, but failed to demonstrate an improved prognosis with delay between injury and surgical intervention. Our study presents clinical experimental outcomes of early keratoplasty but further controlled studies are needed to compare the efficacy and safety of early versus delayed keratoplasty in severe chemical injuries.

Limbal transplantation is effective in restoring corneal epithelium in limbal-deficiency states. Limbal deficiency is a known clinical consequence of severe chemical injury. LAT is preferred to limbal allograft transplantation because allograft requires topical immunosuppression to avoid rejection reaction (Xu et al. 1999). This is most likely because more Langerhans' cells are contained in the limbal area than in the central cornea (Gillette et al. 1982). Combined procedure of limbal allograft transplantation and penetrating keratoplasty resulted in $35.6 \%$ rejection rate in a study by Shimazaki and al. (2001).

With the use of LAT the ocular surface in all eyes was stable at the 6 month evaluation as demonstrated by tear film stability and no erosion. The life span of transient amplifying cells (a compartment of limbal stem cells) is believed to be less than 3 months (Kin os hita et al. 1981). The maintenance of a continuous corneal epithelium for 6 months in our experiment suggests successful LAT and the viability of stem cells.

The third step of our treatment protocol was amniotic membrane transplantation (AM). AM has been frequently used for ocular surface reconstruction for its anti-inflammatory (Choi et al. 1998), anti-scarring (Tseng et al. 1999) and pro-epithelialization effects (Lee and Tseng 1997). AM has been successful in ocular surface reconstruction in both animals and humans (Avila et al. 2001 and Gris et al. 2002), and its use has been reported also in acute chemical and thermal injury (Sridar et al. 2000).

In our study the longest AM attachment to the ocular surface was 2 weeks following surgery (in three of our rabbits) after which it sloughed off. With disappearance of AM we observed corneal erosion only in one eye which healed within three days.

\section{Keratoplastika á chaud, limbálna autotransplantácia a transplantácia amnionovej membrány v liečbe tažkých chemických poranení oka}

Cielom tejto štúdie bolo stanovit účinnosṫ a bezpečnost ošetrenia tažkých chemických poranení oka s použitím keratoplastiky kombinovanej s limbálnou autotransplantáciou a transplantáciou amnionovej membrány. V pokuse bolo použitých 10 samcov novozélandských bielych králikov. Všetky postupy boli uskutočnené v súlade s Pravidlami 
ARVO pre použitie zvierat v oftalmologickom výskume. Poranenia boli indukované $1.5 \mathrm{~N}$ $\mathrm{NaOH}$ v celkovej anestézii. Chirurgický zákrok sme vykonali do 3 dní po poranení. Klinické vyšetrenia nasledovali 2 a 4 týždne, resp. 3 a 6 mesiacov po operácii a zahŕňali vyhodnotenie korneálneho edému, zákalu, vaskularizácie limbálnej ischémie, stability slzného filmu a postoperačnú uveitídu. Boli uskutočnené aj histopatologické vyšetrenia. Raný pooperačný edém a uveitída vymizli do 4 týždňov po zákroku. Počas dvojmesačného obdobia liečby cyklosporínom boli štepy transparentné, potom došlo k ich zakaleniu a vaskularizácii. Pri ukončení sledovania bol slzný film stabilný a neboli zistené žiadne erózie. Na histologických rezoch korneálnych štepov bola zretelná rejekcia a niektoré oblasti limbálnych autotransplantátov vykazovali lahký tkanivový edém s lymfocytmi a lymfoblastovými bunkami.Včasná keratoplastika s limbálnou autotransplantáciou a transplantáciou amnionovej membrány podporujú hojenie povrchu oka, poškodeného silným poleptaním žieravinami. Čírost korneálnych autotransplantátov zostáva zachovaná po dobu trvania imunosupresívnej terapie, po ktorej sa postupne stráca a dochádza k rejekcii štepu. Na stanovenie správneho časovania liečby je potrebné uskutočnit kontrolovanú štúdiu, ktorá by porovnala včasnú a neskorú keratoplasiku kombinovanú s limbálnou autotransplantáciou.

\section{Acknowledgement}

The authors wish to thank Dr. Donald F. Dohn from the Cleveland Clinic Foundation in the United States for his proof-reading and useful comments.

\section{References}

AVILA, M, ESPANA, M, MORENO, C, PENA, C 2001: Reconstruction of ocular surface with heterologous limbal epithelium and amniotic membrane in a rabbit model. Cornea 20: 414-420

CHOI, YS, KIM, JY, WEE, WR, LEE, JH 1998: Effect of application of human amniotic membrane in rabbit corneal wound healing after excimer laser photorefractive keratectomy. Cornea 17: 389-395

GILLETTE, TE, CHANDLER, JW, AND GREINER, JV 1982: Langerhans' cells of the ocular surface. Ophthalmology 89: 700-710

GRIS, O, DEL CAMPO, Z, WOLLEY-DOD, CH, GUELL, JL et al. 2002: Amniotic membrane implantation as a therapeutic contact lens for the treatment of epithelial disorders. Cornea 21: 22-27

KENYON, KR, TSENG, SC 1989: Limbal autograft transplantation for ocular surface disorders. Ophthalmology 96: $709-722$

KINOSHITA, S, FRIEND, J, THOFT, RA 1981: Sex chromatin of donor corneal epithelium in rabbits. Invest Ophthalmol Vis Sci 21: 434-441

KRAMER, SG 1983: Late numerical grading of alkali burns to determine keratoplasty prognosis. Tr Am Ophth Soc 81: $97-106$

LEE, SH, TSENG, SC 1997: Amniotic membrane transplantation for persistent epithelial defects with ulceration. Am J Ophthalmol 123: 303-312

MAHLBERG, K, UUSITALO, RJ, OKSALA, O 1997: Prevention of high risk corneal graft rejection using cyclosporine A (CsA) incorporated into a collagen matrix. Ocular Immunol and Inflamm 5: 101-110

MELLER, D, PIRES, RTF, MACK, RJS et al. 2000: Amniotic membrane transplantation for acute chemical or thermal burns. Ophthalmology 107: 980-989

SCHERMER, A, GALVIN, S, SUN, TT 1986: Differentiation-related expression of a major 64K corneal keratin in vivo and in culture suggests limbal location of corneal epithelial stem cells. J Cell Biol 103: 49-62

SHIMAZAKI, J, MARUYAMA, F, SHIMMURA, S, FUJISHIMA, H. et al. 2001: Immunologic rejection of the central corneal graft after limbal allograft transplantation combined with penetrating keratoplasty. Cornea $\mathbf{2 0}$ : $149-152$

SRIDAR, MS, BANSAL, AK, SANGWAN, VS, RAO, GN 2000: Amniotic membrane transplantation in acute chemical and thermal injury. Am J Ophthalmol 130: 134-137

TSENG, SC, LI, DQ, MA, X 1999: Suppression of transforming growth factor-beta isoforms, TGF-beta receptor type II, and myofibroblast differentiation in cultured human corneal and limbal fibroblasts by amniotic membrane matrix. J Cell Physiol 179: 325-335

WAGONER, MD 1997: Chemical injuries of the eye: current concepts in pathophysiology and therapy [review]. Surv Ophthalmol 41: 275-313

XU, KP, WU, Y, ZHOU, J, ZHANG, X 1999: Survival of rabbit limbal stem cell allografts after administration of cyclosporin A. Cornea 18: 459-465 
Plate XIII

Trbolová A. et al.: Keratoplasty...pp. 571-576

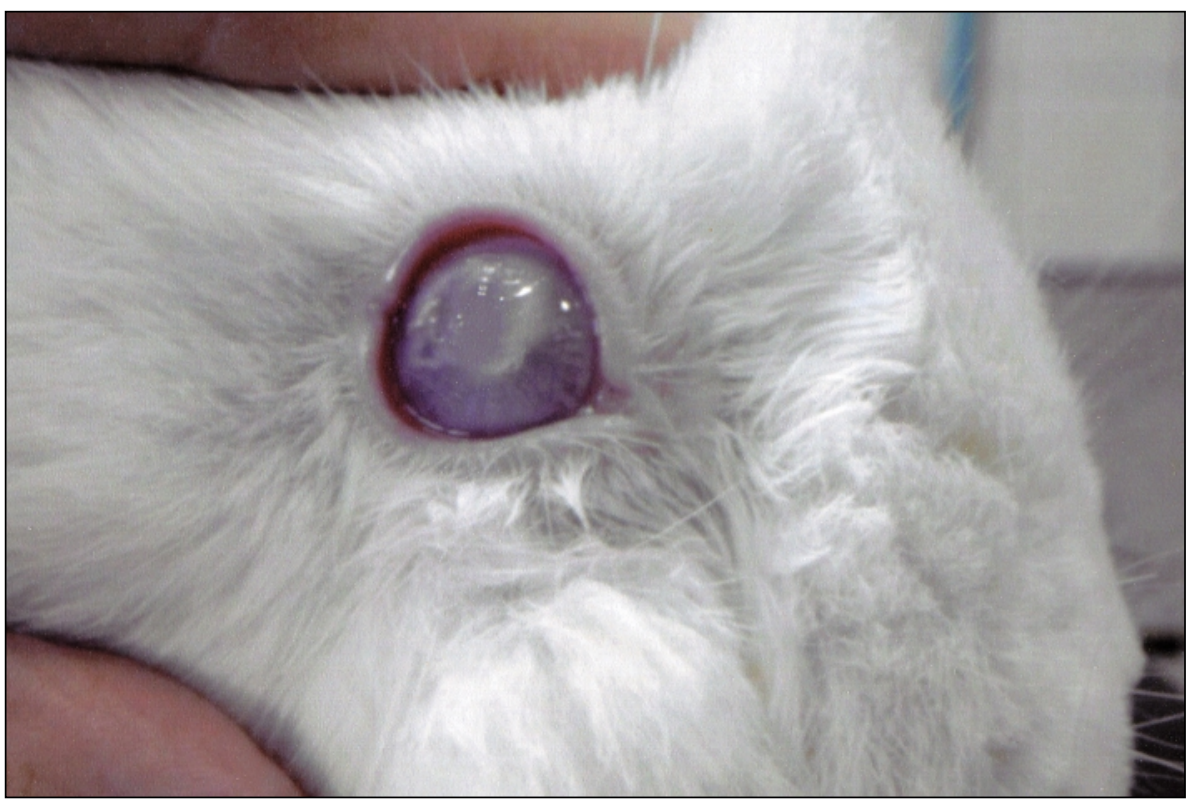

Fig. 1. Chemical eye injury - after three days, opaque cornea, destroyed limbus

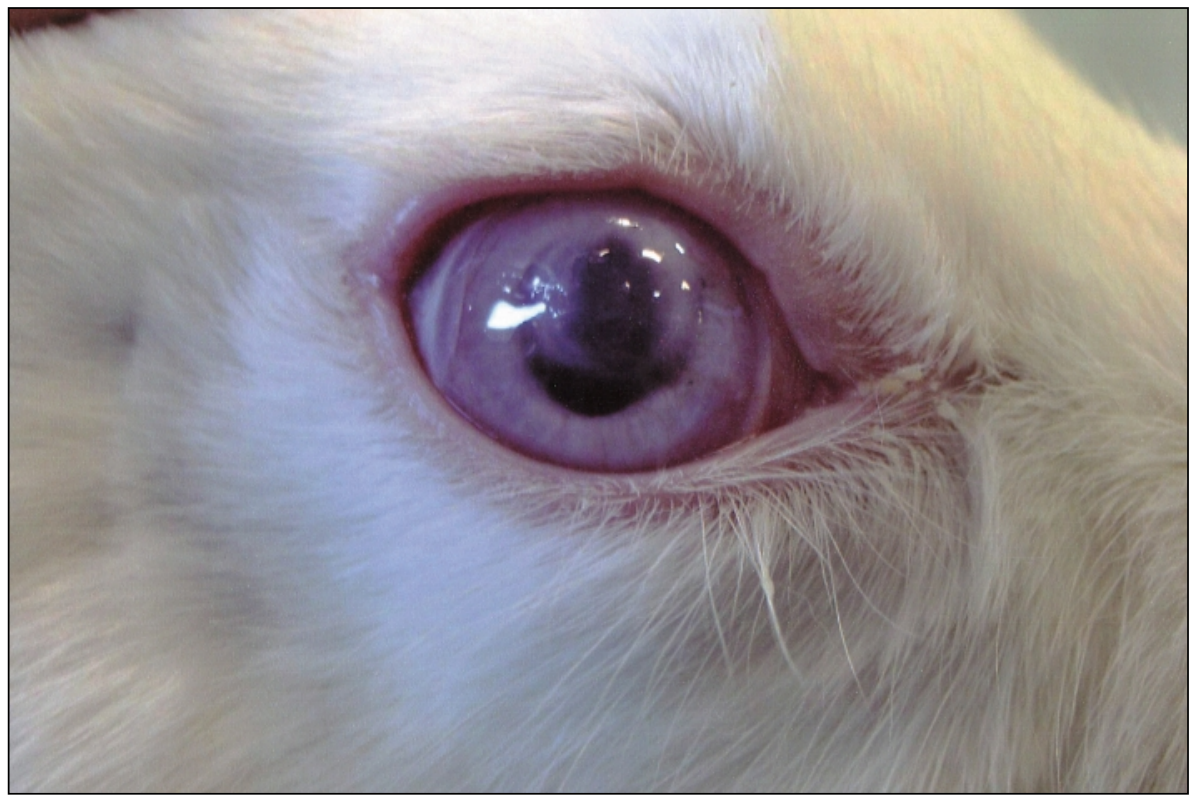

Fig. 2. Eye two months after penetrating keratoplasty and limbal autotransplantation 